Vol. 9, $n^{\circ} 1 \mid 2005$

Varia

\title{
Pieter C. Spierenburg, Written in blood. Fatal attraction in Enlightenment Amsterdam
}

Columbus, Ohio State U.P., 2004, 230 pp., ISBN 0814209556

Martin J. Wiener

\section{(2) OpenEdition}

\section{Journals}

Electronic version

URL: https://journals.openedition.org/chs/399

DOI: $10.4000 /$ chs.399

ISSN: 1663-4837

Publisher

Librairie Droz

Printed version

Date of publication: 1 July 2005

Number of pages: 150-151

ISBN: 978-2-600-01014-6

ISSN: 1422-0857

Electronic reference

Martin J. Wiener, "Pieter C. Spierenburg, Written in blood. Fatal attraction in Enlightenment Amsterdam",

Crime, Histoire \& Sociétés / Crime, History \& Societies [Online], Vol. 9, $n^{\circ} 1$ | 2005, Online since 16 February 2009, connection on 23 March 2022. URL: http://journals.openedition.org/chs/399 ; DOI: https:// doi.org/10.4000/chs.399

This text was automatically generated on 23 March 2022.

(C) Droz 


\title{
Pieter C. Spierenburg, Written in blood. Fatal attraction in Enlightenment Amsterdam
}

Columbus, Ohio State U.P., 2004, 230 pp., ISBN 0814209556

\author{
Martin J. Wiener
}

\section{REFERENCES}

Pieter C. Spierenburg, Written in blood.Fatal attraction in Enlightenment Amsterdam, Columbus, Ohio State U.P., 2004, 230 pp., ISBN 0814209556.

1 Twice within a decade, in 1766 and 1775, women were murdered in Amsterdam out of an excessive love. Are these "two cases of lethal passion in the age of Enlightenment,» as Pieter Spierenburg, author of a number of important works on the history of crime and punishment, calls them, worth the intensive scrutiny of the historian? In this book he makes a convincing case that they are.

2 The genre of «microhistory» that has become well-established in recent years has focused predominantly on crimes and trials, which often provide exceptional amounts of documentation, throwing shafts of light into otherwise dark corners of the past. Spierenburg here follows in that tradition. This book will inevitably be compared to another almost simultaneously published book on an English case of «lethal passion in the age of Enlightenment», John Brewer's A Sentimental Murder, whose subject is the 1779 murder of the mistress of the Earl of Sandwich by an infatuated young clergyman. Yet the two books are hardly comparable, for they take sharply different approaches to the murders they address. Brewer is not much interested in the Ray murder itself, the characters involved or even its immediate social milieu; instead, his concern is for the story that emerged from it, and most of his book is devoted to tracking the way this story was edited, discussed and understood first by contemporaries and then by subsequent generations, changing shape with each retelling. Spierenburg, by contrast, 
stays within the era of the murders he describes, providing a great deal of new information about them, while illuminating their significant place in eighteenthcentury Dutch society and culture. He persuasively argues that these two cases were symptomatic of a larger cultural shift under way - what he calls the «revolution in love,» or what has previously been labeled the «sentimental revolution»- a new emphasis on the quality of one's inner feelings, and on their expression. At the same time, he shows the persistence of older cultural forms, notably the great importance of «honor», in these cases and in the public reactions to them.

Born to a wealthy businessman in the colonial city of Batavia in the Netherlands East Indies, Nathaniel Donker came to Holland at the age of nine. When he defied his family to marry a woman of humble background, he had to endure a legal campaign for annullment, which included his imprisonment on grounds of incompetence in a private jail, but in the end the family efforts failed; love, one might say, won out. However, soon after this victory, Donker's heart was won by another woman of even lower status - a prostitute. A new legal struggle ensued, this time initiated by his wife. This second struggle was concluded when in 1766, at the urging of his new lover, he strangled his wife to death. Found out, tried and convicted, he was executed and his lover imprisoned for life. A few years later, Johannes Van Gogh, a sometime surgeon, actor and hack writer, fell passionately in love with a prostitute. After persistent, humiliating rejection, he fatally stabbed her. He too was executed.

Both cases were public sensations, each yielding an outpouring of news reports and more lengthy tracts. Spierenburg painstakingly reconstructs, from these and from a range of official documents, the course of events of these doomed lives, and sensitively analyzes the public reactions. He manages to recover a surprising amount of information about these ordinary lives (unfortunately but probably inevitably, less about the women than about the men involved). Through this book one can walk the streets and hear the daily life of eighteenth-century Amsterdam. Nor has Spierenburg restricted himself to only what can be established with certainty; he does not hesitate to speculate on motives and inner lives. Yet, in contrast to some practitioners of microhistory, he always does so with caution, clearly marking the points when he leaves the solid ground of ascertainable fact, remaining within the limits of what was «available» to his subjects from the culture of their time and place. Perhaps most valuably, the book contextualizes these two episodes, enabling them to speak to us of a broad yet incomplete cultural shift from an older culture of honor sometimes to an emerging culture of sentiment. The book presents us with two fascinating examples of what he calls the «dark side» of the sentimental revolution.

One wonders, however, if these two cases were quite as Unprecedented as they are portrayed here. Were there no earlier «crimes of passion» in the Netherlands? One can certainly find cases of obsessive love and its tragic consequences in seventeenth- and perhaps sixteenth-century England. Yet this is perhaps asking more than a microhistory can deliver; on its own terms, Written in Blood is accomplishes a great deal. It reveals (and suggests) more of these sad lives and of the Amsterdam of their time than we would have thought possible; and even when venturing into empathetic speculation remains faithful to the framework of ascertained facts. It is a signal contribution to the history of crime and punishment, and as well to the cultural history of early modern Europe. 


\section{AUTHORS}

\section{MARTIN J. WIENER}

Rice University (Houston, Texas, USA),wiener@rice.edu 